\title{
Coil Planet Centrifugal and Capillary Tube Centrifugal Analysis of Factors Regulating Erythrocyte Osmotic Fragility and Deformability
}

\author{
Takashi Nagasawa, Suguru KoJIma, and Eiichi Kimura \\ Department of Physiology, Osaka City University Medical School, \\ Osaka, 545 Japan
}

\begin{abstract}
Hydrated and dehydrated red cell samples were prepared from normal human red cells using the antibiotic nystatin. Furthermore, a series of red cell samples exposed to elevated temperature $\left(20-50^{\circ} \mathrm{C}\right.$, $10 \mathrm{~min}$ ) were prepared. The osmotic fragility and deformability of these red cells were then measured, using the coil planet centrifuge system and the capillary tube centrifugal technique, respectively. The osmotic fragility of nystatin-treated red cells decreased and the deformability increased as dehydration of red cells progressed and alternatively, hydrated cells showed increased osmotic fragility and reduced deformability. Red cells exposed to elevated temperatures up to $49^{\circ} \mathrm{C}$ for $10 \mathrm{~min}$ had no changes in mean corpuscular volume or in red cell shape. Above $47^{\circ} \mathrm{C}$, however, spectrin extractability progressively decreased and osmotic fragility and deformability decreased. Results suggest that the osmotic fragility and deformability of red cells are interrelated, and are controlled by the geometry of the cell, including the ratio of cell surface area to cell volume and the viscoelastic properties of the membrane.
\end{abstract}

Key Words: red cell, deformability, osmotic fragility.

The measurements of erythrocyte osmotic fragility and deformability are useful in screening for hemolytic anemias and are applied to studies of membrane properties. Parpart's method for the osmotic fragility test (PARPART et al., 1947) is a simplified means of estimating the surface area to volume ratio of erythrocytes, but it is a very time consuming procedure as compared with the coil planet centrifuge method (ITO et al., 1966). The deformability of erythrocytes has been shown to be an important factor in reducing the bulk viscosity of blood flowing through vessels and it plays a crucial role in the rheology of blood circulation in the body. Bessis and MoHANDAS (1975) devised the ektacytometer (a laser diffractometric technique) for the measurement of cellular deformability and AllARD et al. (1978) reported using the ektacytometer so that erythrocyte deformation is determined by three major factors: 1) the viscoelastic properties

Received for publication June 11, 1981

長澤貴志, 児島 駿, 木村英一 
of the membrane, 2) the surface area to volume ratio and, 3) the intracellular viscosity. In the present study we prepared hydrated and dehydrated red cells possessing normal membrane permeabilities and heated red cells possessing normal cell shape and mean corpuscular volume, thus designing investigation of the regulating factors of erythrocyte osmotic fragility, deformability, and their relationship using the coil planet centrifuge system and capillary tube centrifugal technique.

\section{MATERIALS AND METHODS}

Preparation of hydrated and dehydrated red cells. Healthy human bloods were drawn into heparinized syringes and the water content of normal red cells was changed by treating with the permeabilizing antibiotic nystatin. To alter the intracellular ion concentration, media containing $27 \mathrm{~mm}$ sucrose, $1.2 \mathrm{~mm}$ $\mathrm{NaCl}$, and $Z \mathrm{mM} \mathrm{KCl}(Z=75,100,125,150,175,200$, and 250) were used (CASs and DALMARK, 1973). Incubation with nystatin $50 \mu 1 / \mathrm{ml}$ (Sigma Chemical Company, U.S.A.) at $4^{\circ} \mathrm{C}$ for $1 \mathrm{hr}$ permitted equilibration of potassium across the membrane. To remove the nystatin the cells were washed three times in nystatinfree medium having the same ion concentration finally reached within the cells and resuspended in isotonic phosphate-buffered saline $(0.12 \mathrm{M} \mathrm{NaCl}, 0.020 \mathrm{M}$ $\mathrm{Na}_{2} \mathrm{HPO}_{4}, 0.005 \mathrm{M} \mathrm{KH}_{2} \mathrm{PO}_{4}, 290$ mOsm, $\mathrm{pH}$ 7.4). Hydration or dehydration of red cells occurred depending on the intracellular potassium concentration and no hemolysis was found during nystatin treatment.

Density distribution of hydrated and dehydrated red cells. Hydrated and dehydrated cells were fractionated on discontinuous gradients of polyvinylpyrrolidone-coated colloidal silica matrix (Percoll; Pharmacia Fine Chemicals AB, Uppsala, Sweden). A stock solution of isotonic Percoll was prepared by the addition of 1 part $10 \times$ Rabinowitz's calcium- and magnesium-free phosphatebuffered saline ( $\mathrm{pH}$ 7.4) to 9 parts Percoll, and this was diluted in Rabinowitz's buffered saline (RABINOwITZ, 1965) to prepare solutions with different density values. Gradients consisted of 10 layers ranging from 1.080 to $1.116 \mathrm{~g} / \mathrm{ml}$. In a typical separation, each $0.5 \mathrm{ml}$ volume of Percoll density media was carefully overlayered in the tube with Pasteur pipettes at $4^{\circ} \mathrm{C}$ and $0.5 \mathrm{ml}$ of sample was layered onto the discontinuous gradients; the tube was then centrifuged at $800 \mathrm{~g}$ for $20 \mathrm{~min}$ at $4^{\circ} \mathrm{C}$.

Heating and spectrin extractability. Red cell suspension was added to the prewarmed phosphate-buffered saline at the specified temperature. The hematocrit was $50 \%$. After incubation for $10 \mathrm{~min}$ the cell suspension was cooled in ice. For spectrin extraction red cell ghosts were prepared by hypotonic lysis (DODGE et al., 1963) and isolated ghost membranes were suspended in 40 volumes of $0.1 \mathrm{~mm}$ EDTA, pH 8.0 (FAIRBANKs et al., 1971) and incubated at $37^{\circ} \mathrm{C}$ for $20 \mathrm{~min}$. The extracted pellets were centrifuged for $30 \mathrm{~min}$ at $10^{4} \mathrm{~g}$. Sodium dodecyl sulfate-polyacrylamide gel electrophoresis (SDS-PAGE) was performed 
as previously described (FAIRBANKS et al., 1971) on membrane proteins using $5 \%$ polyacrylamide gels. Spectrin extractability was evaluated by scanning the SDSPAGE gels of extract pellets and determining the ratio of spectrin: Band 3 from the densitogram.

Dynamic measurement of osmotic fragility of red cells. The osmotic fragility of red cells was measured at $37^{\circ} \mathrm{C}$ by the coil planet centrifuge as previously described (ITo et al., 1966; NAGASAWA et al., 1976). Ten $\mu$ l of red cell suspension in isotonic phosphate-buffered saline (hematocrit, $50 \%$ ) were applied to the coiled tube containing saline with an osmotic gradient. The hemolytic patterns were recorded with a scanning photodensitometer.

Centrifugal measurement of red cell deformability. Red cell deformability was measured by a modified capillary tube centrifugal method (NAGASAwA et al., 1980) of CORRY and MEISELMAN (1978). To observe the deformation of red cells, $5 \mu \mathrm{l}$ of whole blood were suspended in $5 \mathrm{ml}$ of Eagle-MEM (Minimum Essential Medium Eagle with Earle's balanced salt solution) and $50 \mu 1$ of this suspension were placed in the top portion $(1.5 \mathrm{~cm})$ of the siliconized capillary tube $(8 \mathrm{~cm}$ length, $2 \mathrm{~mm}$ inner diameter). The middle portion $(5 \mathrm{~cm})$ of the tube contained isotonic phosphate-buffered saline $(290 \mathrm{mOsm}, \mathrm{pH} 7.4)$. In the bottom portion $(1.5 \mathrm{~cm})$ phosphate-buffered $1 \%$ glutaraldehyde solution $(290-295 \mathrm{mOsM}, \mathrm{pH} 7.4)$ was present to fix the deformed cells. The capillary tube was quickly spun at $12,000 \mathrm{rpm}$ for $1 \mathrm{~min}$ at $37^{\circ} \mathrm{C}$ using the hematocrit centrifuge (Marusan centrifuge Type B-L, Sakuma Co., Ltd., Tokyo) and the red cells were subjected to the centrifugal fields which induced cell deformation. The resulting deformation was evaluated by measuring the elongation of the red cells by a phase contrast microscope.

Measurement of mean corpuscular volume $(M C V)$ of red cells. MCV was calculated by dividing the hematocrit value obtained using the spun hematocrit method $(12,000 \mathrm{rpm}, 5 \mathrm{~min})$ by red cell count.

\section{RESULTS}

Density distribution of hydrated and dehydrated cells

Morphological examination of the dehydrated cells showed a slight flattening of disc and the hydrated cells were progressing from thicker discs to slightly cupped cells. The distribution of nystatin-treated red cells with abnormal water content on discontinuous Percoll gradients is shown in Fig. 1. The water content of normal red cells was varied by changing the intracellular potassium in the presence of the permeabilizing antibiotic nystatin and resuspending them in isotonic phosphate-buffered saline. The dehydrated and hydrated red cells were layered on the higher and lower densities, respectively, shown from left to right in the photograph. 


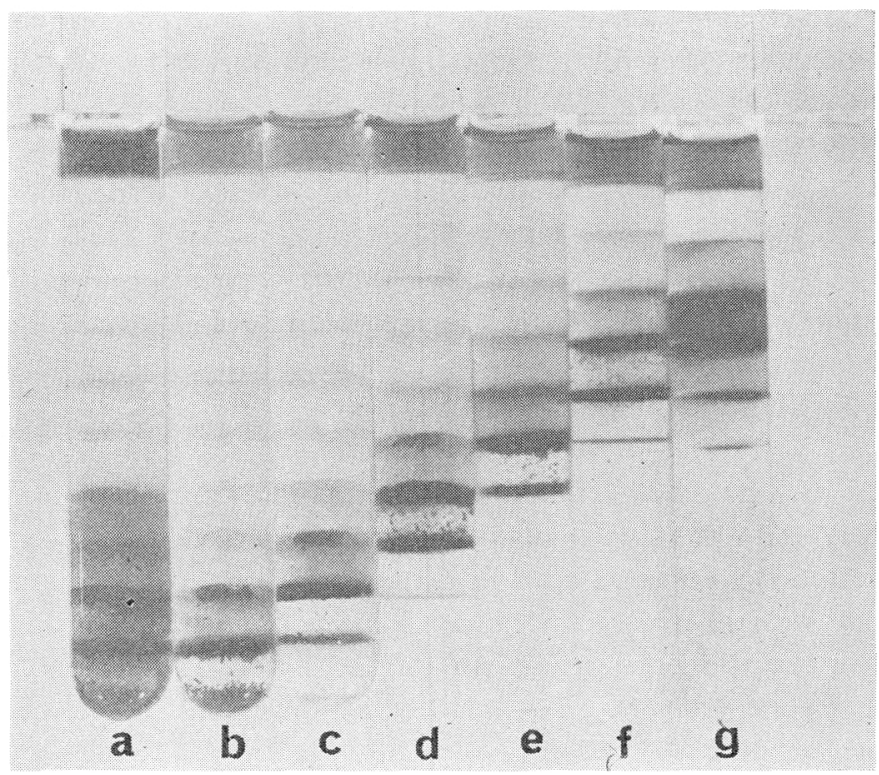

Fig. 1. Density distributions of hydrated and dehydrated red aells by discontinuous Percoll density gradients. Red cells were treated with nystatin in (a) 75, (b) 100, (c) 125, (d) 150, (e) 175 , (f) 200 , and (g) $250 \mathrm{~mm} \mathrm{KCl}$ solutions.

\section{Osmotic fragility and deformability of hydrated and dehydrated cells}

The dynamic measurement of osmotic fragility of hydrated and dehydrated red cells was performed using the coil planet centrifuge (Fig. 2). The dehydrated cells (Fig. 2a-c) show osmotic resistance and the progressively hydrated cells (Fig. 2e-g) increase osmotic fragility with a progressive shift of the hemolytic curve to higher sodium chloride concentration. The deformability of dehydrated and hydrated cells were measured by the capillary tube centrifugal technique, and the deformed shapes of dehydrated and hydrated cells are shown in Fig. 2 top to bottom corresponding to their osmotic fragility curves. The lengths of elongated cells in the longitudinal axis versus the MCV values are shown in Fig. 3. From the results shown in Figs. 2 and 3, cellular dehydration produced increased osmotic resistance and deformability and alternatively, hydration induced the cells to be more fragile and less deformable.

Heat effects on osmotic fragility, deformability, and membrane spectrin

The effects of elevated temperature on osmotic fragility of erythrocytes as measured by the coil planet centrifuge are shown in Fig. 4 . Up to $40^{\circ} \mathrm{C}$, erythrocytes heated for $10 \mathrm{~min}$ produced no changes in osmotic fragility. From 47 to $49^{\circ} \mathrm{C}$ red cells showed a temperature-dependent decrease in osmotic fragility and at $50^{\circ} \mathrm{C}$, however, they suddenly became fragile. The mean corpuscular volume values of heated red cells were measured by the spun hematocrit method. 


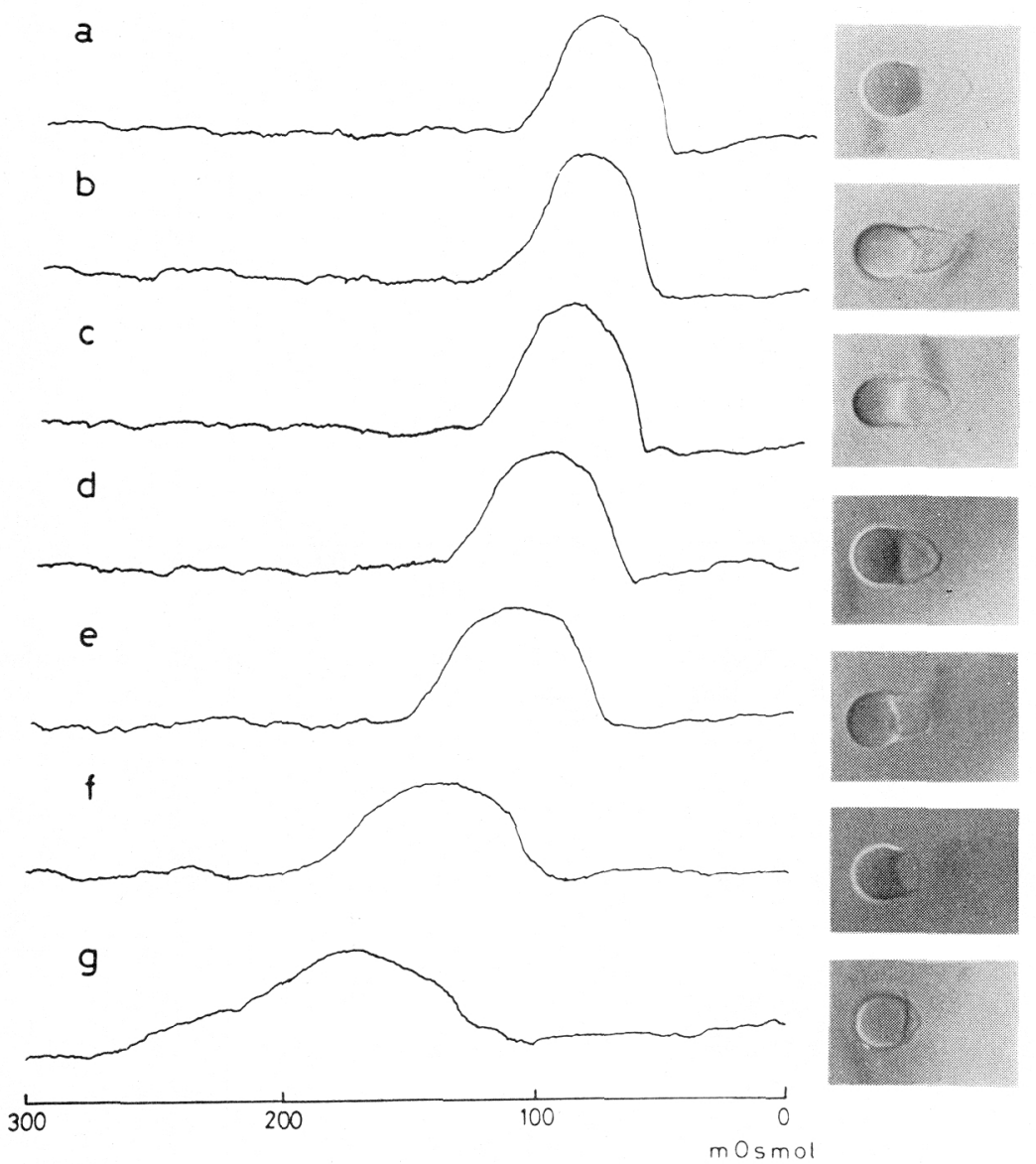

Fig. 2. Osmotic fragility curves of nystatin-treated red cells in (a) 75, (b) 100, (c) 125, (d) 150 , (e) 175 , (f) 200 , and (g) $250 \mathrm{~mm} \mathrm{KCl} \mathrm{solutions.} \mathrm{Microscopic} \mathrm{photos} \mathrm{of} \mathrm{typical}$ cell elongation in centrifugal fields $(12,000 \mathrm{rpm})$ are shown corresponding to their osmotic fragility curves.

$\mathrm{Up}$ to $49^{\circ} \mathrm{C}$ no changes were observed in $\mathrm{MCV}$ and all the cells were discocytes on microscopic observation. At $50^{\circ} \mathrm{C}$ red cells began to be sphere and fragment.

Figure $5 \mathrm{~A}$ shows the effects of heating for $10 \mathrm{~min}$ at various temperatures on deformability of erythrocytes as measured by the capillary tube centrifugal technique. Above $46^{\circ} \mathrm{C}$, red cells showed a progressive temperature-dependent decrease in deformability. Spectrin is rapidly released from the isolated erythrocyte membranes in very low ionic strength media (FAIRBANKs et al., 1971). Figure $5 \mathrm{~B}$ shows that about $80 \%$ of the material in the spectrin position is released from membranes of heated erythrocytes up to $46^{\circ} \mathrm{C}$, while heating about $47^{\circ} \mathrm{C}$ causes a progressive decrease in spectrin extractability with increasing temperature and spectrin becomes unextractable at $49^{\circ} \mathrm{C}$. These results reveal that heating 


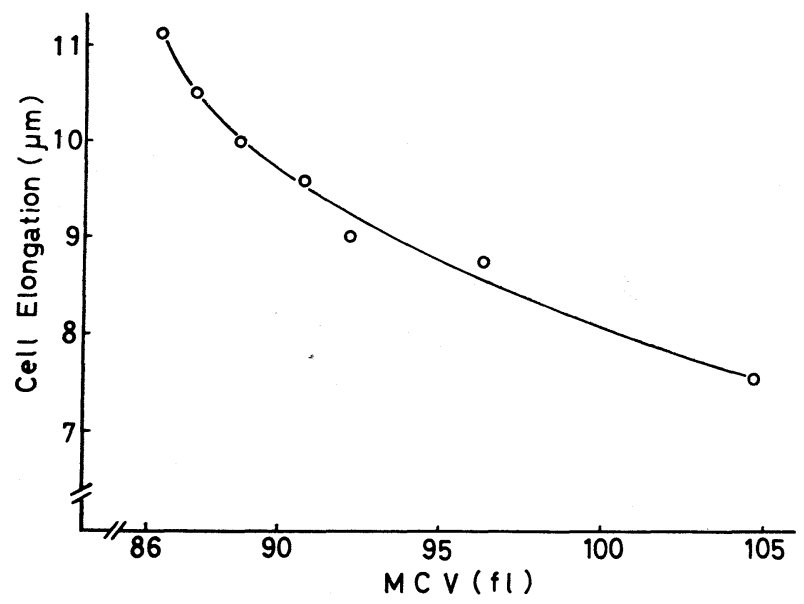

Fig. 3. Deformability of hydrated and dehydrated red cells. Deformability was evaluated as the length of cellular elongation in the centrifugal fields.

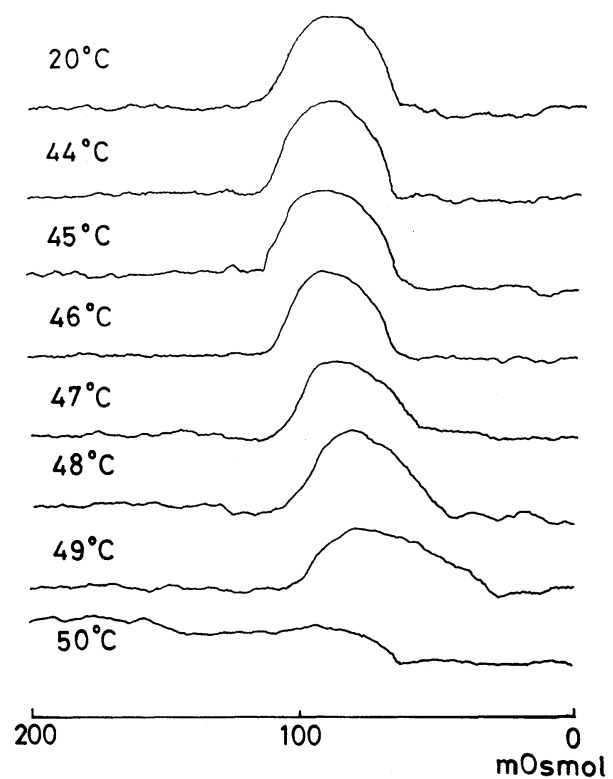

Fig. 4. Osmotic fragility curves of heated red cells at the indicated temperatures measured by the coil planet centrifuge system.

at 47 to $49^{\circ} \mathrm{C}$ for 10 min produces changes in osmotic fragility, deformability, and membrane organization, but not in morphology. 

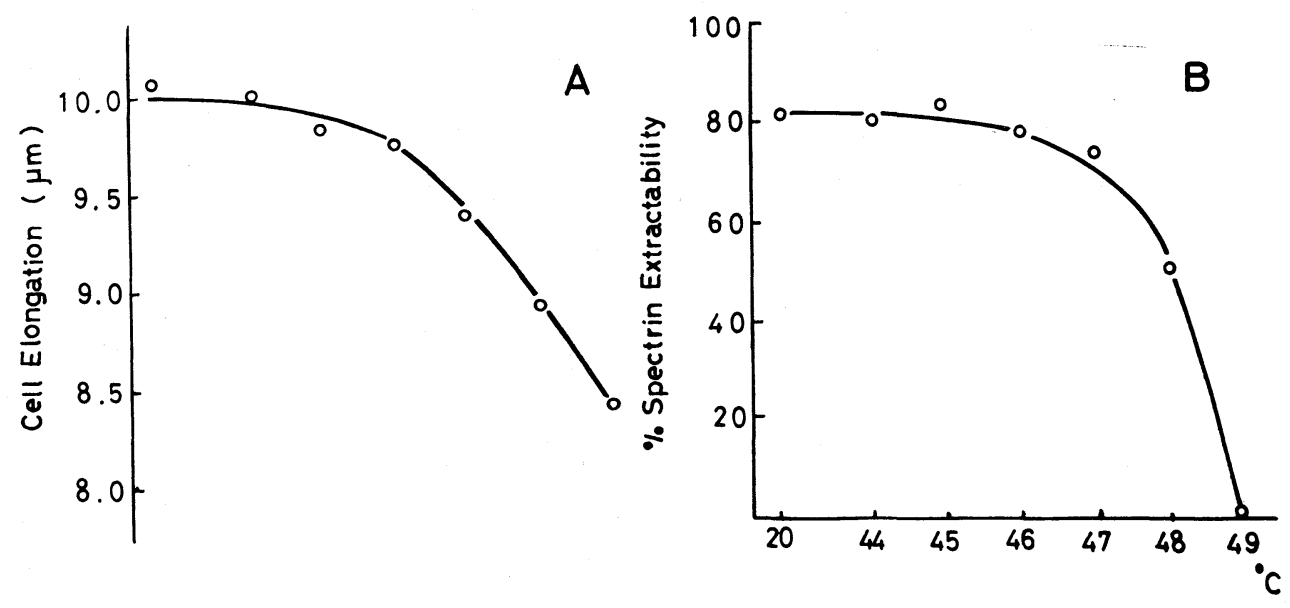

Fig. 5. Deformability and spectrin extractability of heated red cells. (A) Cellular elongation measured by the capillary tube centrifugal method. (B) Extent of spectrin extraction from ghost membranes prepared from erythrocytes exposed for $10 \mathrm{~min}$ at the indicated temperatures.

\section{DISCUSSION}

Changes in the osmotic fragility characteristics of red cells have been used to diagnose and differentiate various hemolytic disorders (Beutler, 1977; Miale, 1972) and to investigate physiological membrane properties (CHAN et al., 1975; DANON, 1963; Davies et al., 1968; Wessels and Veerkamp, 1973, Wessels et al., 1973; ZADE-OPPEN, 1968). Parpart's method (PARPART et al., 1947) and Danon's method (DANON, 1963) used to measure the osmotic fragility of red cells are not suitable for analytical study because of the non-linearized fragiligraph. To improve on this disadvantage, LEON et al. (1970) reported fragiligraph linearization using a computer program to evaluate the toxic or hemolytic actions of drugs and chemicals as well as exotic space-cabin atmospheres. In our study we used the coil planet centrifuge system to measure the osmotic fragility of red cells and obtained a linearized fragiligraph. BEUTLER (1977) has described that the osmotic fragility depends on the surface/volume ratio of erythrocytes. To clarify the regulating factors of osmotic fragility of red cells, we prepared hydrated and dehydrated red cells with a normal ion permeability using the antibiotic nystatin, and heated red cells possessing normal shape, normal MCV and membrane spectrin abnormality. From our experimental results using these red cells, the coil planet centrifuge detected alterations in the surface area to volume ratio and in the viscoelastic properties of the membrane.

Red cell deformability has been measured by the micropipette technique (EvANS and LACELLE, 1975), filtration (CHIEN, 1977), resistive pulse spectroscopy (MEL and YeE, 1975), automated ektacytometer (BESSIS et al., 1980), centrifugal 
elongation (Corry and Meiselman, 1978; Nagasawa et al., 1980), and so forth. According to the ektacytometric study (Allard et al., 1978), red cell deformability was regulated by three factors: internal viscosity, surface area to volume ratio, and viscoelastic modules of the membrane. In the present study regulating factors of deformability were evaluated by the capillary tube centrifugal technique using nystatin-treated red cells and heated red cells. Centrifugal forces deformed the red cells to a handbag-like form. In this shape, the flattened end portion of the cell becomes free of cell contents (Corry and Meiselman, 1978). The degree of displacement of the membrane depends on the membrane deformability since this elongated flattened membrane portion is not affected by the internal viscosity of red cells. When dehydrated cells were studied, they showed increased cellular elongations in the centrifugal fields, depending on their increased surface area to volume ratio. When heated red cells were used, altered membrane properties caused changes in red cell deformation. Experimental results using the capillary tube centrifugal technique indicated that the red cell deformability was predominantly regulated by the surface area to volume ratio of the red cells and by the viscoelasticity of the membrane.

In conclusion, it was revealed by the coil planet centrifuge and the capillary tube centrifugal technique that the osmotic fragility and deformability of red cells were controlled by the relationship of the surface area to volume of the cell and the intrinsic rigidity of the red cell.

\section{REFERENCES}

Allard, C., Mohandas, N., and Bessis, M. (1978) Red cell deformability changes in hemolytic anemias estimated by diffractometric methods (Ektacytometry). In: Red cell Rheology, ed. by Bessis, M., Shohet, S. B., and Mohandas, N. Springer-Verlag, Berlin, pp. 209-221.

Bessis, M. and MoHANDAs, N. (1975) A diffractometric method for the measurement of cellular deformability. Blood Cells, 1: 307-313.

Bessis, M., Mohandas, N., and Feo, C. (1980) Automated ektacytometer: A new method of measuring red cell deformability and red cell indices. Blooa Cells, 6: 315-327.

Beutler, E. (1977) Osmotic fragility. In: Hematology, ed. by Williams, W. J., Beutler, E., Erslev, A. J., and Rundles, R. W. McGraw-Hill, New York, pp. 1609-1610.

CASs, A. and DALmark, M. (1973) Equilibrium dialysis of ions in nystatin-treated red cells. Nature (New Biol.), 244: 47-49.

Chan, T. K., LaCelle, P. L., and Weed, R. I. (1975) Slow phase hemolysis in hypotonic electrolyte solutions. J. Cell Physiol., 85: 47-57.

Chien, S. (1977) Principles and techniques for assessing erythrocyte deformability. Blood Cells, 3: 71-99.

Corry, W. D. and Meiselman, H. J. (1978) Deformation of human erythrocytes in a centrifugal field. Biophys. J., 21: 19-34.

DANON, D. (1963) A rapid micro method for recording red cell osmotic fragility by continuous decrease of salt concentration. J. Clin. Pathol., 16: 377-382.

Davies, H. G., Marsden, N. V. B., Ostling, S. D., and Zade-Oppen, A. M. M. (1968) The effect of some neutral macromolecules on the pattern of hypotonic hemolysis. Acta Physiol. Scand., 74: 577-593. 
Dodge, J. T., Michell, C., and Hanahan, D. J. (1963) The preparation and chemical characteristics of hemoglobin-free ghosts of human erythrocytes. Arch. Biochem. Biophys., 110: 119-130.

Evans, F. A. and LACELle, P. L. (1975) Intrinsic material properties of the erythrocyte membrane indicated by mechanical analysis of deformation. Blood, 45: 29-43.

Fairbanks, G., Steck, T. L., and Wallach, D. F. H. (1971) Electrophoretic analysis of the major polypeptides of the human erythrocyte membrane. Biochemistry, 10: 2606-2617.

Ito, Y., Weinstein, M. A., Aoki, I., Harada, R., Kimura, E., and Nunogaki, K. (1966) The coil planet centrifuge. Nature, 212: 985-987.

Leon, H. A., McTique, M., Ishiguro, G., Card, D., and Fiji, M. (1970) Expansion of the fragiligraph scale by computerization and its use in toxicological investigation. AMLRTR-70-102, Paper 10, Wright-Patterson Air Force Base, Oh., pp. 137-147.

MeL, H. C. and YeE, J. P. (1975) Erythrocyte size and deformability studies by resistive pulse spectroscopy. Blood Cells, 1: 391-399.

Miale, J. B. (1972) Erythrocyte fragility. In: Laboratory Medicine Hematology, ed. by Miale, J. B. The C. V. Mosby Co., Saint Lous, pp. 786-788.

Nagasawa, T., Sudo, K., Nishi, N., Sarashi, A., and Kimura, E. (1976) Graphic analysis of osmotic fragility of erythrocytes. Tohoku J. Exp. Med., 120: 277-285.

NAGASAWA, T., SARASHI, A., and KoJima, S. (1980) A capillary tube centrifugal method for the measurement of cellular deformability. Osaka City Med. J., 26: 1-6.

Parpart, A. K., Lorenz, P. B., Parpart, E. R., Gregy, J. R., and Chase, A. M. (1947) The osmotic resistance (fragility) of human red cells. J. Clin. Invest., 26: 636-640.

RABINOwITZ, Y. (1965) Adherence and separation of leukemic cells on glass bead columns. Blood, 26: 100-103.

Wessels, J. M. C., Pals, D. T. F., and Veerkamp, J. H. (1973) Some aspects of the osmotic lysis of erythrocytes. I. A reexamination of the osmotic lysis method. Biochim. Biophys. Acta, 291: 165-177.

Wessels, J. M. C. and Veerkamp, J. H. (1973) Some aspects of the osmotic lysis of erythrocytes. II. Differences in osmotic behaviour of erythrocytes after treatment with electrolyte and non-electrolyte solutions. Biochim. Biophys. Acta, 291: 178-189.

ZADE-OPPEN, A. M. M. (1968) The effect of mannitol, sucrose, raffinose and dextran on posthypertonic hemolysis. Acta Physiol. Scand., 74: 195-206.

Vol. 32, No. 1, 1982 